\title{
COVID-19 PANDEMIC: UNDER SOME RESTRICTIONS CAN GOVERNMENT'S SUPPORTS GENERATE CUSTOMERS' BEHAVIOR TO BUY? A CASE IN CENTRAL JAVA, INDONESIA
}

\author{
MS. Eric Santosa ${ }^{1}$ \\ ${ }^{1}$ Economics and BusinessFaculty, Stikubank University, Semarang, Indonesia
}

\begin{abstract}
During the pandemic, while there were some restrictions whether relating to income or activity, people's needs were still alive. Any need was always emerging. Whilst the main needs were in duty, the secondary and/or tertiary in some extent could not be overridden. The government provided support and easiness to encourage people to meet their needs. Hopefully, the outbreak did not make the people's live was in sorrow. Something looked like a trend was an emergence of daddies; moms and kids were riding bicycles around the town, usually in a group. It likely was ubiquitous. Obviously, it led to a question; did the pandemic not have a serious effect to people? Could the government's support induce people's buying behavior? The aim of the study was to explore people's buying behaviorin Indonesia, particularly at Central Java, when the government attempted to keep the economy was still in favor.A sample consisted of 120 respondents who lived at Central Java was withdrawn through judgment and convenience technique. Data submitted by questionnaires, employing Likert scale, ranging from $1=$ completely disagree to 5= completely agree. An Amos 22.0 and SPSS 21.0 were exercised to analyze data. The finding showed that people's buying behavior was initiated by their intention. The government's supports and easiness didn't significantly influence the people's need.
\end{abstract}

KEYWORDS: needs, attitude, intention to buy, buying behavior.

Article Received: 10 August 2020, Revised: 25 October 2020, Accepted: 18 November 2020

1. INTRODUCTION

Indonesia, like other countries, has been suffering. The Covid-19 has been widespread among countries. It is believed the disease has killed 16,646 people in Indonesia, and 1,458,093 people in the world. The amount likely potentially increases since 527,999 people in Indonesia are still infected, and 362,562,850 people in the world are positively confirmed.

Unlike other countries, Indonesia doesn't apply a locked down system. It operates such condition which is called 'large scaled social restriction' (PSBB). The PSBB is not totally employed in the whole country, only areas which have high case of infection and death, and have epidemic relation with other areas within or beyond the country. Contrasting with a locked down system, the PSBB still allows particular people to interact and move, but restricted. Schools, colleges and universities are suggested not to operate. Malls and other shopping places should close. Offices and other work places are recommended to work from home (WFH). Only particular offices may still operate which under condition as follows: those who deal with defense and security, public orderliness, foods, oil \& gas, health services, economics, finances, communications, industries, export and import, and logistic distributions. However, in general people will be better off if they stay at home.

Recently, though in some particular areas the PSBB still works, majority areas is on new normal condition. This condition is looser than PSBB. Churches and mosques are open, though under control of health protocol. The protocol confirms that people should allow the rule of $3 \mathrm{M}$ that is, washing hand, using mask and keeping distance. Those who break the regulation are worthy to be penalized. Other activities such in the work place, shopping place and other social activities are slightly permitted, but firmly should obey the $3 \mathrm{M}$ rule.

Under the new normal era people likely should be thankful to the government. Though they are suggested to stay at home, but for the sake of specific matters, they can still leave their house to meet their needs such as foods, cloths and other needs. Also they can go beyond to meet their families or friends. In point of fact, the government strives to generate economic 
activities, utilizing the power of consumption to push the economic growing rate. Several malls and retailers are open under control of the health protocol; some workplaces are allowed to operate to alleviate job cessation (PHK).

As a matter of fact, the government commiserates people of their suffering because of the pandemic. Some labors have a half of wage during temporarily 'homed'. Even, some have no wage at all when they are likely pushed to have a rest. Some employees are rescheduled interchangeably which in effect they only get a half. In some extent, a lot of labors and employees get job cessation (PHK). Thereby, it is a great phenomenon that in general people have their income diminished.

The government eggs on every party to help people's purchasing power. The Social Ministry develops such financial support to people, which called 'cash direct allowance' (BLT). It also distributes such support of basic needs. The Finance Ministry encourages financial institutions to lengthen credit tenors, to lessen rate of interests and to omit fines. Other ministries also participate to lighten household burden such as reducing tariff of electric use or transferring pulse to students and teachers.

People are encouraged to have a small business. They might sell food, fruit, vegetables; sell basic needs; sell something that in demand; sell something that utilizing opportunities; delivering services such as massage, cutting hair, beauty treatment etc. In short, people are driven to do everything to lighten their burden by doing business.

Something likely surprising is the growing amount of men, women and children ride bicycle go along the streets at downtown or peripheries. The phenomenon is very prominent during the pandemic. They appeared any time, in the morning, at noon, afternoon, even in the evening. It happens not only in a one town, but likely any town in Indonesia has the same trend. Brands such as Brompton, Cannondale, Giant, GT Bike, Polygon, Wimcycle, United, Specialized, Trek, Santa Cruz, Kona, Fuji, Element, Thrill, Pacific, are very popular among Gowes (a terminology for bikers). As a matter fact, some bicycles are not cheap, their price range from 15 to 60 million rupiahs. While for low-priced variants have prices at least 2 million rupiahs for adults and 1 million rupiahs for children. The fact leads us to think, how can they meet the need, since not only the dad, but also the mom and the kids? For riches, possibly they still have reserves, but for those who are in the middle and low income how can they prioritize the special need and override other needs?

However, the question is likely not the main purpose of the study. Apparently, the study is purported to investigate the effect of the government's supports on fulfilling people's need, implicitly a particular need, during the pandemic.

Actually, during the pandemic a lot of researches have been carried out. Most are inherent with the disease itself, such as the cause, taking care of, signs and symptoms, how to prevent, the effects etc. Here the following some researchers that consider the study. Brown et al. (2020) investigate the critical care of the Covid19. Chai et al. (2020) examine the convalescent plasma or hyper immune immunoglobulin for people with Covid-19. Struyf et al. (2020) bring about study of signs and symptoms to determine if a patient has Covid-19. Streit et al. (2020) accomplish a study about quarantine alone or in combination with other public health measures to control Covid-19. Deeks et al. (2020) undertake a study about antibody tests for identification of current and past infection with SARS-Cov-2.

Burns et al, (2020) get done a study about travel-related control measures to contain the Covid-19 pandemic. Muller et al. (2020) execute a research about hand cleaning with ash for reducing the spread of viral and bacterial infections. Verbeek et al. (2020) explore a research about personal protective equipment for preventing highly infectious diseases due to exposure to contaminated body fluids in healthcare staff. Jefferson et al. (2020) scrutinize a study about physical interventions to interrupt or reduce the spread of respiratory viruses. Anglemyer et al. (2020) investigate a study about digital contact tracing technologies in epidemics. Pfeferbaum \&North(2020) delve into research about mental health and the Covid-19 pandemic. Khalifa \& Sharfeldin (2020) examine a research about prevalence and socio-behavioral factors associated with depressive disorders among primary health care physicians during Covid-19 pandemic. Gaur et al. (2020) suggest employing unified approach to detect Covid-19 in patients. Mohan \& Bhuvaneswari (2020) investigate about management of head and neck surgeries during Covid-19 pandemic. Khare et al. (2020) execute a study about evaluation of the effects of Covid-19 on the general dental practices.

Some particular studies which does not emphasize to the disease itself are as follows. Biriowu \& Chris-Biriowu (2020) explore about 
the impact of public opinion formation on global power, economic and employment relations. Ghosh (2020) inspects about the Covid-19 pandemic and the socio economic security threats in India. Slobodianiuk et al. (2020) delve into a study of rights of business entities due to the pandemic from the perspective of administrative legal support. Qodir et al. (2020) deliver a study about government communication to induce a positive perspective among the public concerning the Covid-19 outbreak. Yudheksa et al. (2020) provide a research about a need to revisit the teaching learning process as per the needs and demands during the pandemic. Praba Devi \& Lavanya (2020) do a research about effect of digital queuing app for Covid-19 prevention in the grocery consumption at Tamilnadu. Patil \& Das (2020) execute a study about means of marketing communication strategies used by real estate developers in India during the Covid-19 pandemic.

The study which is recently being carried out is likely different. While the government provides some supports and easiness during the pandemic, can the policy lead people's buying behavior be still in favor? Can the policy encourage people to meet their needs? For the sake of respondents limitation the research just be conducted at Central Java only.

2. FORMULATING HYPOTHESES

Human's life could not be separable with needs. Such basic needs, for instance food, drinks, clothes etc. is an obligation. People could not defend their live without these primary basic needs. Conversely, they are likely still alive though secondary basic needs are distant. Actually, not only do basic needs, people always strive to meet other needs. How much they can satisfy of meeting their needs, it likely depends on their income. The higher income people get, the more purchasing power they have, and the more satisfied in fulfilling the needs will be. On the contrary, during the pandemic, it is common of rescheduling the fulfillment since the income is diminished. Based on the point of view, a hypothesis could be formulated as follows:

$\mathrm{H} 1$ : Income Restriction (IR) has a significant influence to Needs $(\mathrm{N})$

Under the PSBB (large scaled social restriction), the government narrows people's activity such as a suggestion to stay at home, alleys close, transport limitation, etc. People are expected not to go around. The basic idea is to cut the spreading of the virus. Since the rule is not so tight, people are still allowed to do something, such as buying or selling something. Frankly speaking the restriction likely has no effect to needs. So, the $\mathrm{H} 2$ can be formed as follows:

H2: Mobile Restriction (MR) has not a significant influence to Needs (N)

The government attempts to keep people's economy does not fall considerably. A BLT (cash direct allowance) conferral, basic needs (normally called sembako, nein basic daily commodities) distribution, full salaries arrangement and such other packages are programmed. The purpose is to lighten people's burden. Logically, it will support people's purchasing power. So, it is hypothesized:

H3: Support $(\mathrm{S})$ has a significant influence to Needs $(\mathrm{N})$

While the government's support likely lead people to pay attention to particular needs, they begin to evaluate particular products. It is common they appraise from price and quality. If so, it can be hypothesized as follows:

H4: Support (S) has a significant influence to Perceived Value (PV)

The programs of credit tenor prolongation, rate of interest reduction, fines omission and tariff of electric use decrease are assumed not significantly increase people's purchasing power. The idea is that the programs just lessen the people's burden. It likely does not lead people to attend other needs. So, it is hypothesized as follows:

H5: Easiness (E) has not a significant influence to Needs (N)

When somebody feels there is something special make him/her is in interest, he/she automatically assesses the particular product at least from two aspects, i.e. price and quality. The attentiveness actually is a result of the assessment process. So, it could be hypothesized:

H6: Needs (N) has a significant effect to Perceived Value (PV)

When an assessment of a particular product meets the expectation, it makes somebody excited. In some extent, he/she is proud of the product. Liking the product is seemingly unavoidable, and a positive impressed is in favor. Studies of Molina \& Saura (2008) and Neno (2019) indicate that perceived value influences attitude. So, it can be hypothesized as follows:

H7: Perceived Value (PV) has a significant effect to Attitude (Ab)

Theory of planned behavior (TPB) (Ajzen, 1991) denotes that attitude is predictor of behavioral intention. Likewise, studies of Jyh 
(1998); Okun \& Sloane (2002); Martin \& Kulinna (2004); Wiethoff (2004); Marrone (2005); Kouthouris \& Spontis (2005); and Santosa (2016). So, a next hypothesis is as follows:

H8: Attitude ( $\mathrm{Ab}$ ) has a significant effect to Intention to Behave (IB)

The TPB also proclaims that behavioral intention is a predictor of behavior. Likewise, studies of Jyh (1998); Okun \& Sloane (2002); Martin \& Kulinna (2004); Wiethoff (2004); Marrone (2005); Kouthouris \& Spontis (2005); and Santosa (2016). So, a next hypothesis is as follows:

H9: Intention of Behavior (IB) has a significant effect to Buying Behavior (BB)

3. RESEARCH MODEL

Based on the hypotheses proposed, a research model could be drawn as at Fig. 1.

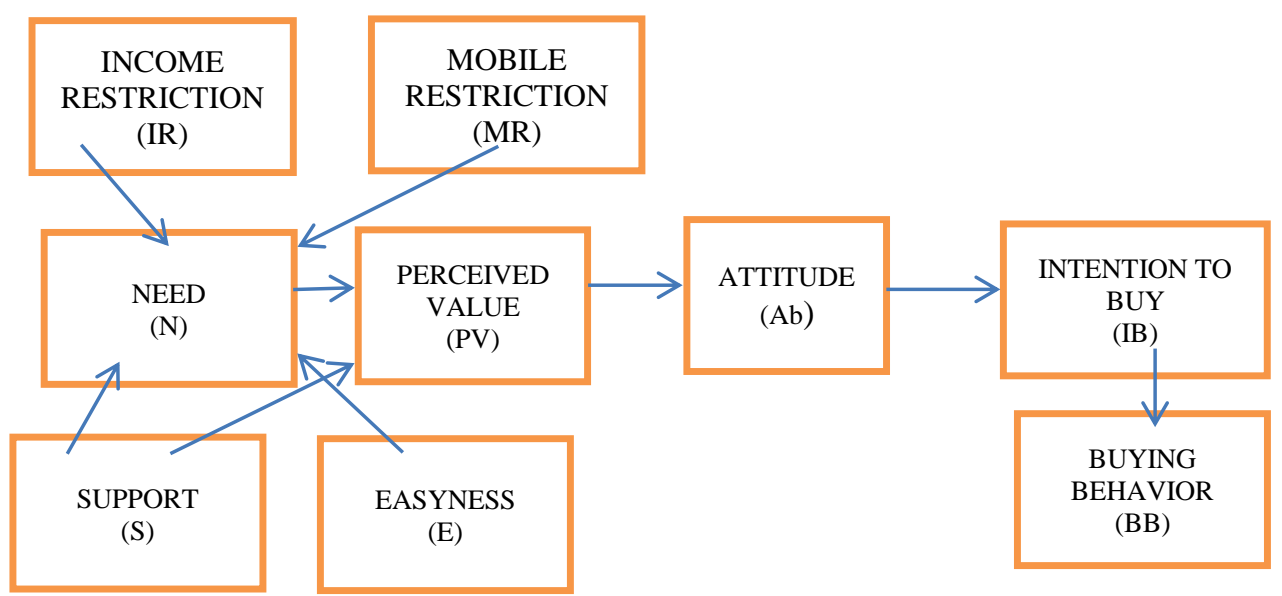

Figure 1. Research Model

4. METHODS

A sample of 120 respondents is withdrawn applying convenience and judgment technique (Cooper \& Schindler 2008). Respondents are those who stay at cities in Central Java. Questionnaire technique is in use employing Likert scale 5 points, ranging from $1=$ completely not agree to $7=$ completely agree, and distributed through WhatsApp Group. The instrument is tested by exercising confirmatory factor analyze and Cronbach's alpha. Data are analyzed by the use of AMOS 22.0 and SPSS 21.0.

5. RESULTS
3.1Test of Validity

The confirmatory factor analyze produces output that loading factor of N2, N3. N4, IR1, IR2, IE3, IR4, IR5 IR6, IR7, IR8, IR9, IR10, MR1, MR2, MR3. MR4, S1, S3, S3, S4, S5, S6, S7, S8, S9, E1, E2, E3, E4, E5, E6, E7, PV1, PV2, PV3, PV4, PV5, PV6, PV7, PV8, PV9, PV10, b1, b2, b3, b4, b5, ev1, ev2, ev3, ev4, ev5, IB1, IB2, IB3, IB4, BB1, BB2, BB3 and BB4 are more than 0.5 . Thereby, the indicators are valid (Ghozali, 2008) (Table 1). Only N1, IR 11 and E6 those are not valid. 
Table 1. The Validity of N, IR, MR, S, E, PV, Ab, IB and BB

\begin{tabular}{|c|c|c|c|}
\hline Variables & Item & Loading Factor & Criterion \\
\hline $\mathrm{N}$ & $\begin{array}{l}\mathrm{N} 1 \\
\mathrm{~N} 2 \\
\mathrm{~N} 3 \\
\mathrm{~N} 4\end{array}$ & $\begin{array}{l}0.359 \\
0.643 \\
0.581 \\
0.548\end{array}$ & $\begin{array}{l}\text { Not Valid } \\
\text { Valid } \\
\text { Valid } \\
\text { Valid }\end{array}$ \\
\hline IR & $\begin{array}{l}\text { IR1 } \\
\text { IR2 } \\
\text { IR3 } \\
\text { IR4 } \\
\text { IR5 } \\
\text { IR6 } \\
\text { IR7 } \\
\text { IR8 } \\
\text { IR9 } \\
\text { IR10 } \\
\text { IR11 }\end{array}$ & $\begin{array}{l}0.689 \\
0.740 \\
0.735 \\
0.707 \\
0.721 \\
0.675 \\
0.753 \\
0.766 \\
0.780 \\
0.558 \\
0.280 \\
\end{array}$ & $\begin{array}{l}\text { Valid } \\
\text { Valid } \\
\text { Valid } \\
\text { Valid } \\
\text { Valid } \\
\text { Valid } \\
\text { Valid } \\
\text { Valid } \\
\text { Valid } \\
\text { Valid } \\
\text { Not Valid }\end{array}$ \\
\hline MR & $\begin{array}{l}\text { MR1 } \\
\text { MR2 } \\
\text { MR3 } \\
\text { MR4 }\end{array}$ & $\begin{array}{l}0.883 \\
0.848 \\
0822 \\
0.716\end{array}$ & $\begin{array}{l}\text { Valid } \\
\text { Valid } \\
\text { Valid } \\
\text { Valid }\end{array}$ \\
\hline $\mathrm{S}$ & $\begin{array}{l}\text { S1 } \\
\text { S2 } \\
\text { S3 } \\
\text { S4 } \\
\text { S5 } \\
\text { S6 } \\
\text { S7 } \\
\text { S8 } \\
\text { S9 }\end{array}$ & $\begin{array}{l}0.750 \\
0.690 \\
0.603 \\
0.746 \\
0.762 \\
0.670 \\
0.688 \\
0.759 \\
0.621\end{array}$ & $\begin{array}{l}\text { Valid } \\
\text { Valid } \\
\text { Valid } \\
\text { Valid } \\
\text { Valid } \\
\text { Valid } \\
\text { Valid } \\
\text { Valid } \\
\text { Valid }\end{array}$ \\
\hline$E$ & $\begin{array}{l}\text { E1 } \\
\text { E2 } \\
\text { E3 } \\
\text { E4 } \\
\text { E5 } \\
\text { E6 } \\
\text { E7 } \\
\end{array}$ & $\begin{array}{l}0.748 \\
0.767 \\
0.591 \\
0.666 \\
0.607 \\
0.277 \\
0.765 \\
\end{array}$ & $\begin{array}{l}\text { Valid } \\
\text { Valid } \\
\text { Valid } \\
\text { Valid } \\
\text { Valid } \\
\text { Not Valid } \\
\text { Valid } \\
\end{array}$ \\
\hline PV & $\begin{array}{l}\text { PV1 } \\
\text { PV2 } \\
\text { PV3 } \\
\text { PV4 } \\
\text { PV5 } \\
\text { PV6 } \\
\text { PV7 } \\
\text { PV8 } \\
\text { PV9 } \\
\text { PV10 }\end{array}$ & $\begin{array}{l}0.613 \\
0.761 \\
0.807 \\
0.754 \\
0.793 \\
0.766 \\
0.658 \\
0.771 \\
0.791 \\
0.700\end{array}$ & $\begin{array}{l}\text { Valid } \\
\text { Valid } \\
\text { Valid } \\
\text { Valid } \\
\text { Valid } \\
\text { Valid } \\
\text { Valid } \\
\text { Valid } \\
\text { Valid } \\
\text { Valid }\end{array}$ \\
\hline $\mathrm{b}$ & $\begin{array}{l}\text { b1 } \\
\text { b2 } \\
\text { b3 } \\
\text { b4 } \\
\text { b5 }\end{array}$ & $\begin{array}{l}0.796 \\
0.898 \\
0.864 \\
0.742 \\
0.733\end{array}$ & $\begin{array}{l}\text { Valid } \\
\text { Valid } \\
\text { Valid } \\
\text { Valid } \\
\text { Valid }\end{array}$ \\
\hline ev & $\begin{array}{l}\text { ev1 } \\
\text { ev2 } \\
\text { ev3 }\end{array}$ & $\begin{array}{l}0.712 \\
0.691 \\
0.871\end{array}$ & $\begin{array}{l}\text { Valid } \\
\text { Valid } \\
\text { Valid }\end{array}$ \\
\hline
\end{tabular}




\begin{tabular}{|c|c|c|c|} 
& ev4 & 0.841 & Valid \\
\hline IB & ev5 & 0.845 & Valid \\
& IB1 & 0.704 & Valid \\
& IB2 & 0.794 & Valid \\
& IB3 & 0.542 & Valid \\
\hline BB & IB4 & 0.504 & Valid \\
& BB1 & 0.886 & Valid \\
& BB2 & 0.758 & Valid \\
& BB3 & 0.864 & Valid \\
& BB4 & 0.786 & Valid \\
\hline
\end{tabular}

Source: Amos output

\subsection{Test of Reliability}

Table 2 shows that variables IR, MR, $\mathrm{S}, \mathrm{E}, \mathrm{PV}, \mathrm{b}, \mathrm{ev}, \mathrm{IB}$ and BB have Cronbach's alpha score more than 0.6. It means that all

Table 2. The Reliability of Ab, SN, PBC, IS, RC and S

\begin{tabular}{|c|c|c|}
\hline Variable & Cronbach's alpha & Justification \\
\hline N & 0.381 & Not Reliable \\
IR & 0.902 & Reliable \\
MR & 0.836 & Reliable \\
S & 0.833 & Reliable \\
\hline
\end{tabular}

to be continued .....................

\begin{tabular}{|c|l|l|}
\hline E & 0.817 & Reliable \\
PV & 0.918 & Reliable \\
b & 0,820 & Reliable \\
ev & 0.816 & Reliable \\
IB & 0.755 & Reliable \\
BB & 0.838 & Reliable \\
\hline
\end{tabular}

Source: data analyses

\subsection{Structural Equation Modeling}

An initial structural equation model is drawn by connecting all variables as hypothesized. However, it doesn't work. The software just wants to calculate when Justification

Reliable

Reliable variables are reliable (Ghozali, 2013) (Table 2). Only variable $\mathrm{N}$ that its Cronbach's alpha is less than 0.6. variance/covariance is connected as suggested. The model shows that all indicators lead to goodness of fit (Fig.2, Table 3) 


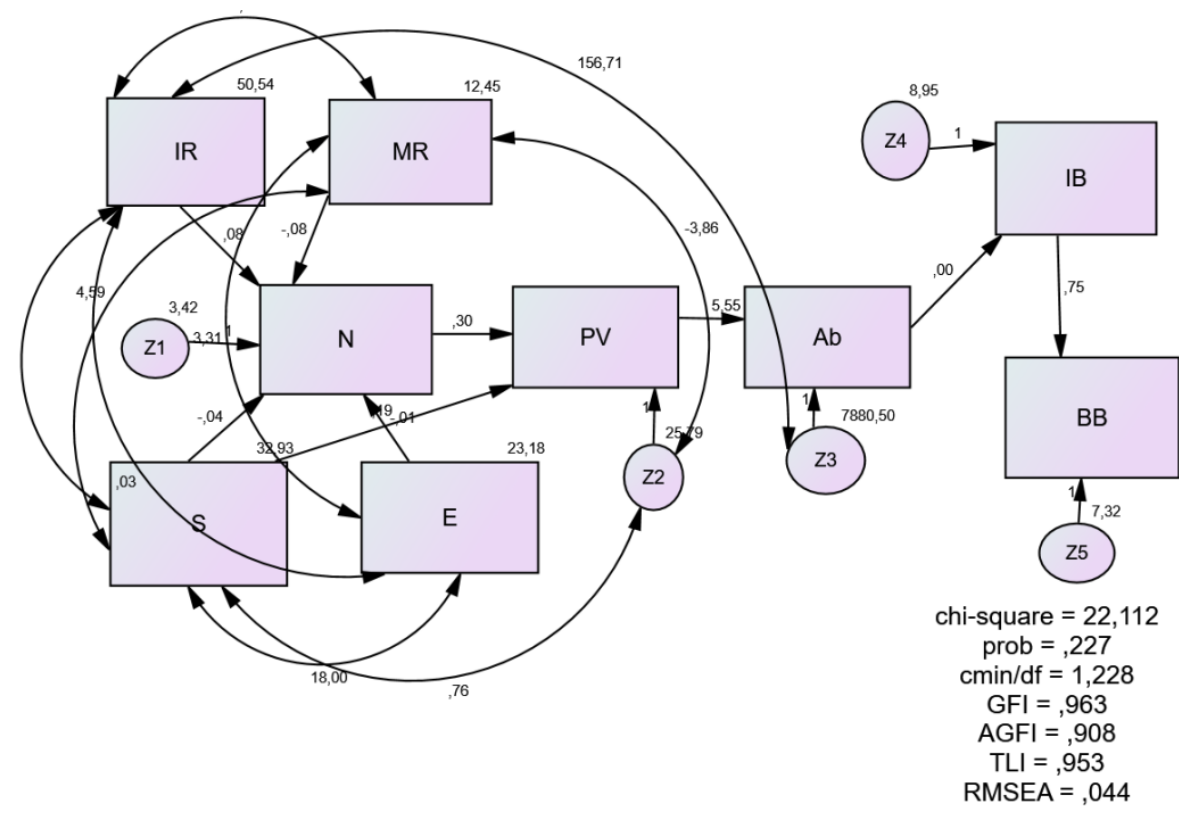

Figure 2. The Model in Use

Table 3. Indicators of the Model in Use

\begin{tabular}{|c|c|c|c|}
\hline indicators & The Model in use & Threshold & Criterion \\
\hline Chi-sq/Probability & $22.112 / 0.227$ & $37.697 / 0.05$ & Meet the criterion \\
Cmin/df & 1.228 & $\leq 5$ & Meet the criterion \\
\hline
\end{tabular}

to be continued ....................

\begin{tabular}{|c|c|c|l|}
\hline GFI & 0.963 & High & Meet the criterion \\
AGFI & 0.908 & $\geq 0,9$ & Meet the criterion \\
TLI & 0.953 & $\geq 0,9$ & Meet the criterion \\
RMSEA & 0.044 & 0,05 to 0,08 & Meet the criterion \\
\hline
\end{tabular}

Source: data analyses

3.4 Test of Hypotheses

Table 4. Regression Weight among Variables

\begin{tabular}{|c|c|c|c|c|c|c|c|}
\hline & & & Estimate & S.E. & C.R. & $\mathrm{P}$ & Label \\
\hline $\mathrm{N}$ & $<--$ & IR & 0.077 & 0.024 & 3.189 & 0.001 & par_1 \\
\hline $\mathrm{N}$ & $<--$ & MR & -0.077 & 0.050 & -1.542 & 0.123 & par_2 \\
\hline $\mathrm{N}$ & $<--$ & S & -0.039 & 0.039 & -0.979 & 0.328 & par_3 \\
\hline $\mathrm{N}$ & $<--$ & $\mathrm{E}$ & -0.006 & 0.047 & -0.125 & 0.900 & par_4 \\
\hline PV & $<--$ & $\mathrm{N}$ & 0.304 & 0.236 & 1.290 & 0.197 & par_5 \\
\hline PV & $<---$ & S & 0.194 & 0.125 & 1.549 & 0.121 & par_18 \\
\hline $\mathrm{Ab}$ & $<--$ & PV & 5.548 & 1.502 & 3.694 & $* * *$ & par_6 \\
\hline IB & $<--$ & $\mathrm{Ab}$ & 0.003 & 0.003 & 1.178 & 0.239 & par_7 \\
\hline $\mathrm{BB}$ & $<---$ & IB & 0.746 & 0.083 & 9.000 & $* * *$ & par_8 \\
\hline
\end{tabular}

Source: Amos output

Table 4 shows that the influence of IR to $\mathrm{N}$ is significant $(\mathrm{p}=0.001)$. Likewise the influence of $\mathrm{PV}$ to $\mathrm{Ab}(\mathrm{p}=0.000)$, and the influence of IB to $B B(p=0.000)$. It means that $\mathrm{H} 1, \mathrm{H} 7$ and $\mathrm{H} 9$ are supported. Although the influence of $\mathrm{MR}$ to $\mathrm{N}$ and $\mathrm{E}$ to $\mathrm{N}$ are not significant, it actually corresponds to what that hypothesized. So, H2 and H5 are supported.
The influence of $\mathrm{S}$ to $\mathrm{N}$ is also not significant $(\mathrm{p}=0.328)$. Similarly, the insignificant influences of $N$ to $P V(p=0.197) ; S$ to PV $(\mathrm{p}=0.121)$ and Ab to IB $(\mathrm{p}=0.239)$ In this case, the evidences do not support $\mathrm{H} 3, \mathrm{H} 6$, $\mathrm{H} 4$, and $\mathrm{H} 8$. 


\section{DISCUSSION}

During pandemic people's needs are inevitable. They have to be fulfilled. The problem is how to meet the needs. The result shows that the needs $(\mathrm{N})$ are influenced by income restriction (IR). While the income diminishes (such as a reduction of wage, alimony, hard to be a part-timer, etc.), the needs are also restricted and required to reschedule. The support of H1 is likely natural. Likewise, the mobile restriction (such as the suggestion to stay at home, alleys close, transport limitation, etc.) likely does not have a straight effect to the needs. The support of $\mathrm{H} 2$ is also undoubtedly.

The not supported of $\mathrm{H} 3$ might be clarified as follows. In some extent such financial support i.e. BLT (cash direct allowance) and others, actually might lead to strengthen the purchasing power. However, it might be not in general. In other words, it only occurs for some particular people, while for the rest it doesn't. H4 is also not supported. The financial support and basic needs distribution might help people in meeting their needs. Similarly the electric tariff reduction might people elude to meet other needs. Nevertheless it might happen for some people only, not at a whole. Thereby, it is understandable that $\mathrm{H} 4$ is also not supported.

H5 declares that Easiness (E) has not a significant influence to Needs (N). It is actually hypothesized that such lengthening of credit tenors, lessening of rate of interest and omitting of fines could not lead people to rapidly buy something. The empirical data vigorously support the idea. Thereby, H5 is obviously encouraged.

It is hypothesized that needs $(\mathrm{N})$ have a significant effect to perceived value (PV) (H6). While people require to a particular need, they are led to judge at least from two aspects, i.e. quality and price. The relation of requirement and judgment is sequential. However, it is not the case when the need is hard to be realized since the power to purchase is weak. The empirical data which support $\mathrm{H} 1$ are evidence. As a consequence, $\mathrm{H} 6$ is not supported. Meeting the needs is not a priority. Conversely, a favorable need leads people to judge the object. While people begin to judge particular product from quality and price, they will have favorable attitude when the quality and price meet their expectation. The confirmation of $\mathrm{H} 7$ is a consequence. The more beneficial the product the more positive the attitude will be. So, the support of $\mathrm{H7}$ is not rare. The result is appropriate with the study of Molina \& Saura (2008) and Neno (2019).

Ajzen (1991), in theory of planned behavior (TPB), confirms that attitude has a significant effect to behavioral intention. So it is hypothesized as well that Attitude $(\mathrm{Ab})$ will have a significant effect to
Intention to Behave (IB) (H8). However, the empirical data do not support H8. It might be interpreted that although the people's attitude is positive they do not have an intention to buy something since the income restriction is in effect. In addition, the product(s) might be supposed as product(s) that come(s) in a sudden. Probably, the product(s) belong(s) to abnormal needs. The result is absolutely not in line with Jyh (1998); Okun \& Sloane (2002); Martin \& Kulinna (2004); Wiethoff (2004); Marrone (2005); Kouthouris \& Spontis (2005); and Santosa (2016). Instead, it is similar with Carvalho's study (2007).

H9 which denotes to the influence of Intention to Behave to Buying Behavior is hypothesized based on Ajzen's TPB. The empirical data support the hypothesis, in which it also corresponds with Jyh (1998); Okun \& Sloane (2002); Martin \& Kulinna (2004); Wiethoff (2004); Marrone (2005); Kouthouris \& Spontis (2005); and Santosa (2016).

\section{CONCLUSION}

The reduction of income during the Covid19 pandemic is unavoidable. Some policies such as a reduction of working hour and job cessation lead labor and employees have their wage diminished, even ended. The difficulty of getting part timer jobs lets people have more suffering. So, the condition leads people to live in impediment. However, the needs could not be ceased. People need something to eat, money to pay electrical disbursement, require children's clothes, household stuff, even equipment, etc. The government's support likely could not make people's burden be easier. People are still in restriction to buy something.

While a need of something in favor, such asa bicycle, becomes prominent, since it is supposed as a way to elude the sorrow, an intention to buy is seemingly blur. A positive judgment of the need does not generate an intention. The reality that at last some people purchase bicycles is probably is not a normal sequence. It looks like a suggestion effect and planned product category of impulse buying (Kotler \& Keller, 2013). Frankly speaking, a question is still not yet answered in this study, that is, how can some people get money to buy bicycles?

\section{REFERENCES}

[1] M. Brown, et al. Corona virus (COVID-19): evidence relevant to critical care. Cochrane Special Collections. 22 December 2020.

[2] K.L. Chai et al. Convalescent plasma or hyper immune immunoglobulin for people with COVID-10: a living systematic review. Cochrane Database of Systematic Reviews. 12 October, 2020. 
[3] T. Struyf et al. Signs and symptoms to determine if a patient presenting in primary care or hospital outpatient settings has COVID-19 disease. Cochrane Special Collections. 07 July, 2020.

[4] B.N.Streit et al. Quarantine alone or in combination with other public health measures to control COVID-19: a rapid review. Cochrane Special Collections. 14 September, 2020.

[5] J.J. Dekks, et al. Antibody tests for identification of current and past infection with SARS-CoV-2. Cochrane Special Collections. 25 June, 2020.

[6] J. Burns, et al. Travel-related control measures to contain the COVID-19 pandemic: a rapid review. Cochrane Special Collections. 16 September, 2020.

[7] A.S.P Muller, et al. Hand cleaning with ash for reducting the spread of viral and bacterial infections: a rapid review. Cochrane Special Collections. 28 April, 2020.

[8] J.H. Verbeek, et al. Personal protective equipment for preventing highly infectious diseases due to exposure to contaminated body fluids in healthcare staff. Cochrane Special Collections. 15 May, 2020.

[9] T. Jefferson, et al. Physical interventions to interrupt or reduce the spread of respiratory viruses. Cochrane Special Collections. 20 November, 2020.

[10] A. Anglemyer. Digital contact tracing technologies in epidemics: a rapid review. Cochrane Special Collections. 18 August, 2020.

[11] B. Pfefferbaum \& C.S. North. Mental health and the Covid-19 pqndemic. The New English Journal Medicine. 383. 510-512. August 6, 2020.

[12] A.M. Khalifa \& A.Y. Sharfeldin. Prevalence and socio behavioral factors associated with depressive disorders among primary health care physicians in Shebin El-kom district, Menoufia Goveronrate, Egypt, during Covid-19 pandemic. International Journal of Research in Humanities, Arts and Literature, Vol 8. (12). 79-92. Dec. 2020.

[13] P.K.Gaur et al. Unified approach to detect Covid-19 in patients. Journal of Critical Reviews. Vol.7. (19). 2518-2523. 2020.

[14] A.M. Mohan \& M. Bhuyaneswari. Management of head and neck surgeries during Covid-19 pandemic: practical strategy. Journal of Critical Reviews. Vol.7. (19).3592-3600. 2020.
[15] V.V.Khare et al. Evaluation of the effects of Covid-19 on the general dental practicesoriginal research. Journal of Consumer Research. Vol.7. (19). 3601-3607. 2020.

[16] C.S. Biriowu \& T.B. Chris-Birowu. Problem-reaction-solution thesis and Covid19: the impact of public opinion formation on global power, economic and employment relations. International Journal of Research in Humanities, Arts and Literature. Vol 8. (5). 41-48. May 2020.

[17] N. Ghosh. The Covid-19 pandemic and the socio economic security threats in India. International Journal of Research, Arts and Literature. Vol. 8. (11). 31-46. Nov. 2020.

[18] M.Slobodianiuk, et al. Rights of business Entities due to the pandemic (Covid 19): administrative-legal support. Journal of Consumer Research. Vol.7. (15). 51-58. 2020.

[19] Z. Qodir, et al. The role of the leader in a pandemic: government communication to induce positive perspective among the public concerning the Covid-19 outbreak. Journal of Critical Reviews. Vol.7. (15). 2735. 2020.

[20] G.K.Yudheksa, et al. Implications of elearning during the pandemic: a need to revisit the teaching-learning process as per the needs and demands. Journal of Critical Reviews. Vol.7. (15). 3552-3559. 2020.

[21] M.N. Praba Devi \& K. Lavanya. Effect of Digital Queuing app. for Covid-19 prevention in the grocery consumption @ Tamilmadu: a randomized trial. Journal of Critical Reviews. Vol.7. (15).3690-3695. 2020.

[22] P. Patil \& J. Das. To study means of marketing communication strategies used by real estate developers in India during the Covid-19 pandemic. International Journal of Research in Humanities, Arts and Literature. Vol.8. (10). 91-98. Oct 2020.

[23] M.E.R. Molina \& I.G. Saura. Perceived value, customer attitude and lyalty in retailing. Journal of Retail \& Leisure Property, 7, 305-314. 2008.

[24] D.N.Neno. Efek mediasi pada pengaruh nilai produk, harga dan citra merek terhadap sikap pelanggan dan dampaknya pada niat beli- studi pada pengguna smarphone Samsung di Feb Unisbank Semarang. Equilibrium, vol XIII. (2). pp 10-37. 2019.

[25] I. Ajzen. The theory of planned behavior. Organizational Behavior and Human Decision. Processes. 50. pp 179-211. 1991. 
[26] S.C.Jyh. The Effect of attitude, subjective norm, and perceived behavioral control on consumers' purchase intentions: the moderating effects of product knowledge and attention to social comparison information. Proc.Natl. Sci. Counc. ROC (C). 9.(2).. pp 298-308. 1998.

[27] M.A. Okun and E.S. Sloane. Application of planned behavior theory to predicting volunteer enrollment by college students in a campus-based program. Social Behavior and Personality. Tempe: Arizona State University. 2002.

[28] J.J. Martin and P.M. Kulinna. Selfefficacy theory and theory of planned behavior: teaching physically active physical education classes. Research Quarterly for Exercise and Sport, Vol. 75.(3), 288 - 297. 2004.

[29] C. Wiethoff.. Motivation to learn and diversity training: application of the theory of planned behavior. Human Resource Development Quarterly, Vol. 15.(3).2004.

[30] S.R.Marrone. Attitudes, subjective norms, and perceived behavioral control: critical care nurses' intentions to provide culturally congruent care to Arab Muslims. Research Report.Columbia University Teachers College. 2005.(unpublished).

[31] C.H. Kouthouris and A. Spontis. Outdoor recreation participation: an application of the theory of planned behavior. The Sport Journal, Vol. 8,(3), United States Sport Academy. 2005.

[32] M.S.E. Santosa. Compromise effect oncConsumer's Decision making. Journal of Indonesian Economy and Business (JIEB) UGM. vol 31 No 3. pp. 325-344. Sep 2016.

[33] D.R. Cooper and P.S. Schindler. Business Research Methods. Boston: McGrawHill/Irwin. 2008.

[34] I. Ghozali. Model Persamaan Struktural: Konsep dan Aplikasi dengan Program Amos Ver 16.0. Semarang: BP Undip. 2008.

[35] I. Ghozali. Aplikasi Analisis Multivriate Dengan Program IBM SPSS 21 Update PLS Regresi Edisi 7. Semarang: Badan Penerbit Universitas Diponegoro. 2013.

[36] C.A.Carvalho. Impact on consumer attitude in predicting purchasing behavior. .Available at http://www.iaso.com.br/pdf. Accessed at January 5, 2021.

[37] P. Kotler \& K.L. Keller. Marketing Management. $14^{\text {th }}$ ed. Harlow, England: Pearson Education Limited. 2013.
[38] Ineji, Patrick Ukim. "POLITICS AND PROPAGANDA IN THE COVID-19 ERA: THE NIGERIAN SITUATION." IMPACT: International Journal of Research in Humanities, Arts and Literature (IMPACT: IJRHAL) 8.12 (2020) 113-120

[39] Almetwally, Ehab M., and M. I. Gamal. "Discrete Alpha Power Inverse Lomax Distribution with Application of COVID-19 Data." International Journal of Applied Mathematics \& Statistical Sciences (IJAMSS) 9.6 (2020) 11-22.

[40] NGUYEN, DONGTHI THAO, and THU CHUNG KIEUTHI. "NEW TRENDS IN TECHNOLOGY APPLICATION IN EDUCATION AND CAPACITIES OF UNIVERSITIES LECTURERS DURING THE COVID-19

PANDEMIC." International Journal of Mechanical and Production Engineering Research and Development (IJMPERD) 10.3 (2020) 1709-1714.

[41] Garg, Commodore Vijesh, and Annie Sam. "ENGAGEMENT OF NATIONAL CADET CORPS (NCC) CADETS IN DISASTER RISK MITIGATION UNDER PANDEMIC COVID-19: A CASE STUDY OF TAMILNADU, PUDUCHERRY AND ANDAMAN \& NICOBAR ISLANDS." IMPACT: International Journal of Research in Applied, Natural and Social Sciences (IMPACT: IJRANSS) 8.6 (2020) 15-24.

[42] Yousuf, Rizwan, Khalid Ul Islam Rather, and Saima Farhat. "UNEXPECTED RAMIFICATIONS OF CORONA PANDEMIC ECONOMIC AND STATISTICAL ISSUES." IMPACT: International Journal of Research in Business (Management IMPACT: IJRBM) 8.9 (2020): 27-32.

[43] Khalifa, Amr Moustafa, and Asmaa Yahia Sharfeldin. "PREVALENCE AND SOCIOBEHAVIOURAL FACTORS ASSOCIATED WITH DEPRESSIVE DISORDERS AMONG PRIMARY HEALTH CARE PHYSICIANS IN SHEBIN EL-KOM DISTRICT, MENOUFIA GOVERONRATE, EGYPT, DURING COVID 19 PANDEMIC." IMPACT: International Journal of Research in Humanities, Arts and Literature (IMPACT: IJRHAL) 8.12 (2020) 79-92 